\title{
Paracoccus sulfuroxidans sp. nov., a sulfur oxidizer from activated sludge
}

Correspondence

Shuang-Jiang Liu

liusj@sun.im.ac.cn

\author{
Xing-Yu Liu, ${ }^{1,2}$ Bao-Jun Wang, ${ }^{1}$ Cheng-Ying Jiang ${ }^{1}$ \\ and Shuang-Jiang Liu ${ }^{1}$
${ }^{1}$ State Key Laboratory of Microbial Resources, Institute of Microbiology, Chinese Academy of Sciences, Zhong-Guan-Cun, Haidian, Beijing 100080, P. R. China
${ }^{2}$ Graduate University of Chinese Academy of Sciences, Beijing 100049, P. R. China

Bacterial strain $\mathrm{LW} 36^{\top}$ was isolated from activated sludge of a wastewater-treatment bioreactor. Cells of strain $\mathrm{LW}_{3}{ }^{\top}$ were Gram-negative coccoids to short rods, $1.0-1 \cdot 2 \times 0.5 \mu \mathrm{m}$ in size. Colonies were cream-coloured, smooth and circular. Strain $L W 36^{\top}$ was hetero-organotrophic and chemolithotrophic and was able to use reduced sulfur as an energy resource. Growth was observed at $25-36{ }^{\circ} \mathrm{C}$ and $\mathrm{pH} 5-10$. The most abundant cellular fatty acid of strain LW36 ${ }^{\top}$ was $\mathrm{C}_{18: 1} \omega 7 \mathrm{c}$ $(64 \cdot 2 \%)$. The sole respiratory quinone was ubiquinone-10. The $\mathrm{G}+\mathrm{C}$ content of the genomic DNA was $61.3 \mathrm{~mol} \%\left(T_{\mathrm{m}}\right)$. 16S rRNA gene sequence analysis indicated that strain $\mathrm{LW}^{\mathrm{T}}{ }^{\top}$ was phylogenetically related to members of the genus Paracoccus, with similarities ranging from 92.4 to $94.9 \%$. Based on these results, it is concluded that strain $L W 36^{\top}$ represents a novel species of the genus Paracoccus, for which the name Paracoccus sulfuroxidans is proposed. The type strain is strain LW36 ${ }^{\top}\left(=\right.$ CGMCC $\left.1.5364^{\top}=J C M 14013^{\top}\right)$.
The genus Paracoccus was first erected by Davis et al. (1969) and the description was emended by Katayama et al. (1995). At the time of writing, the genus comprises 19 recognized species (see Fig. 1). Members of this genus are metabolically versatile and are widely distributed in soil, sediment and activated sludge environments. They take part in bioconversion of organic and inorganic compounds. For example, Paracoccus denitrificans utilizes organic compounds for growth and can use nitrate for respiration (Rainey et al., 1999, and references therein). Some other Paracoccus species, such as Paracoccus pantotrophus (Robertson \& Kuenen, 1983; Rainey et al., 1999), Paracoccus thiocyanatus and Paracoccus versutus, can use reduced sulfur as an energy source (Harrison, 1983; Katayama et al., 1995). In this study, a sulfur-oxidizing, heterotrophic bacterial strain, designated LW $36^{\mathrm{T}}$, was isolated from activated sludge. Based on phenotypic and genotypic studies it is concluded that this isolate represents a novel species of the genus Paracoccus.

Bacterial strain $\mathrm{LW} 36^{\mathrm{T}}$ was isolated from activated sludge of a sequential batch reactor treating mixed wastewater containing various nitroaromatic compounds (nitrobenzene, nitrophenol, 2,4-dinitrophenol) and aniline. The sludge sample was suspended in sterile saline solution by using vigorous

The GenBank/EMBL/DDBJ accession number for the $16 \mathrm{~S}$ rRNA gene sequence of strain $\mathrm{LW}^{\top} 6^{\top}$ is D0512861.

A scanning electron micrograph of cells of strain $L W 36^{\top}$ and a table showing its cellular fatty acid profile are available as supplementary material in IJSEM Online. vortexing, and a portion of the suspension was spread directly on LB agar plates. The plates were incubated at $30{ }^{\circ} \mathrm{C}$ for about a week. Single colonies on the plates were picked up and bacterial strain $\mathrm{LW}^{\mathrm{T}}{ }^{\mathrm{T}}$ was obtained by repeatedly streaking cultures on new plates from a single colony.

Routine cultivation was conducted at $30^{\circ} \mathrm{C}$ with $\mathrm{LB}$ media. Gram reactions were determined according to the method described by Gerhardt et al. (1994). Presence of cell flagella and cell morphology were examined by transmission electron microscopy (H600; Hitachi) and scanning electron microscopy (FEI QUANTA 200). Growth temperature range was determined with a $\mathrm{TN} 3 \mathrm{~F}$ temperature-gradient incubator (Advantec). Catalase and oxidase activities, the Voges-Proskauer reaction, carbon source utilization and other biochemical characterization methods were performed according to Dong \& Cai (2001). For testing growth on reduced sulfur and elemental sulfur, strain LW $36^{\mathrm{T}}$ was inoculated into Allen's medium (Allen, 1959), the $\mathrm{pH}$ of which was adjusted to $6 \cdot 5$, supplemented with elemental sulfur $(1 \%)$, sulfide $(1 \%)$, thiosulfate $(1 \%)$ or sulfite $(1 \%)$. Cell growth was estimated either by monitoring the increase in optical density at $600 \mathrm{~nm}$ or by determining the increase in protein content of cultures.

Cells of strain LW36 ${ }^{\mathrm{T}}$ were Gram-negative, coccoid to short rods with a size range of $1 \cdot 0-1 \cdot 2 \times 0.5 \mu \mathrm{m}$ (see Supplementary Fig. S1 in IJSEM Online). Colonies were cream-coloured, smooth, circular and $0.4-2.0 \mathrm{~mm}$ in diameter. Growth was observed over a temperature range 


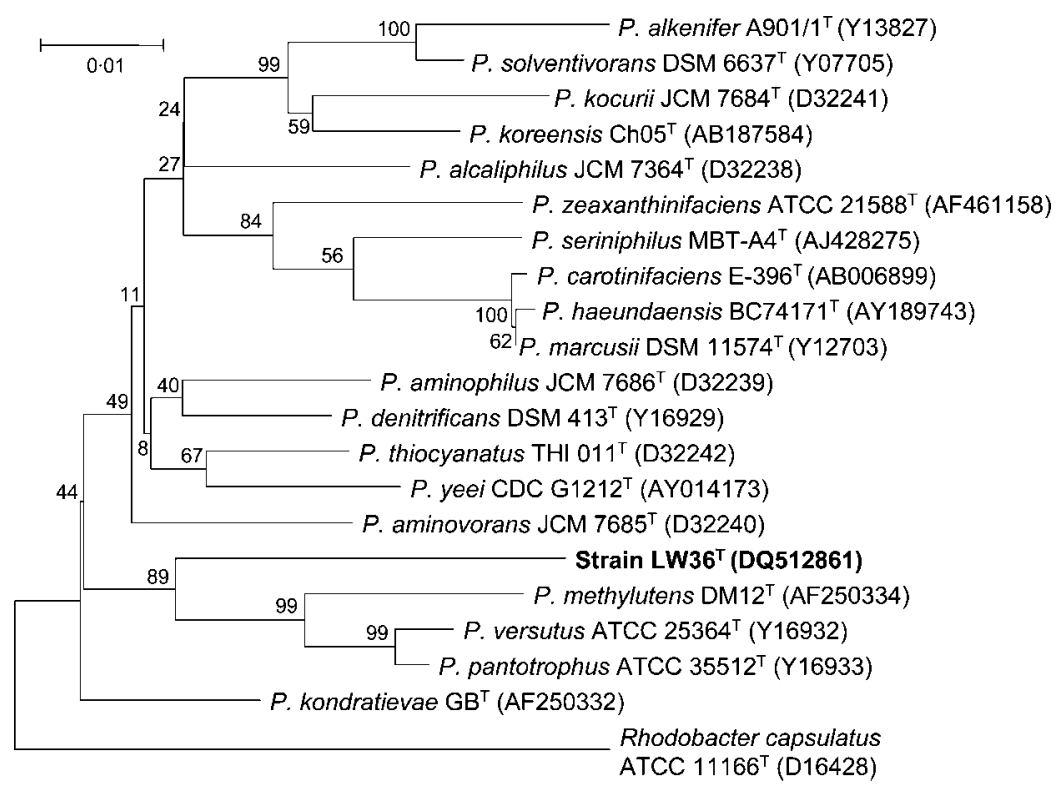

Fig. 1. Phylogenetic tree constructed with the neighbour-joining method according to 16S rRNA gene sequence evolutionary distances among strain $\mathrm{LW} 6^{\top}$ and recognized members of the genus Paracoccus. Rhodobacter capsulatus ATCC $11166^{\top}$ was used as the outgroup. Bar, evolutionary distance $\left(K_{\text {nuc }}\right)$ of 0.01 . of $25-36^{\circ} \mathrm{C}$ and a $\mathrm{pH}$ range of $5-10$. Strain $\mathrm{LW} 36^{\mathrm{T}}$ grew chemolithotrophically on thiosulfate, sulfide and elemental sulfur but growth was not observed with sulfite. Other physiological and biochemical characteristics are given in Table 1 and in the species description below.

Biomass for chemotaxonomic analyses was harvested from $\mathrm{LB}$ cultures at $30^{\circ} \mathrm{C}$ after incubation for $24 \mathrm{~h}$. Cellular fatty acids were extracted and analysed as described by $\mathrm{Hu}$ et al. (2004). Quinones were extracted and purified according to the method of Collins (1985) and were analysed by HPLC (Wu et al., 1989), with a commercial ubiquinone-10 (Q-10) sample (China Pharmacy Corp.) as reference. Results showed that the major cellular fatty acids $(>1 \%$ of the total) of strain $\mathrm{LW}^{\mathrm{T}}{ }^{\mathrm{T}}$ were $\mathrm{C}_{18: 1} \omega 7 \mathrm{c}(64 \cdot 2 \%), \mathrm{C}_{16: 0}$ $(16 \cdot 4 \%), \mathrm{C}_{18: 0}(3 \cdot 7 \%), \mathrm{C}_{14: 0} 3-\mathrm{OH}(3 \cdot 0 \%), \mathrm{C}_{16: 1} \omega 7 c$ $(2 \cdot 3 \%), \mathrm{C}_{14: 0}(1 \cdot 9 \%)$, iso- $\mathrm{C}_{15: 1}(1 \cdot 8 \%)$ and $\mathrm{C}_{19 \mathrm{cyc}}(1 \cdot 4 \%)$. Detailed information on the cellular fatty acid composition of strain $\mathrm{LW} 36^{\mathrm{T}}$ is provided in Supplementary Table S1 in IJSEM Online. Strain $\mathrm{LW}_{3} 6^{\mathrm{T}}$ had Q-10 as the sole respiratory quinone. DNA base composition was determined by thermal denaturation (Marmur \& Doty, 1962), with Escherichia coli $\mathrm{K}-12$ as reference. The DNA G +C content of strain $\mathrm{LW} 36^{\mathrm{T}}$ was $61 \cdot 3 \mathrm{~mol} \%$.

Table 1. Phenotypic characteristics that differentiate strain $L W 36^{\top}$ from related species of the genus Paracoccus

Taxa: 1, strain LW36 ${ }^{\mathrm{T}}$; 2, P. denitrificans (data from Doronina et al., 1998; Dworkin, 2001); 3, P. methylutens (Doronina et al., 1998; Dworkin, 2001); 4, P. versutus (Katayama et al., 1995; Dworkin, 2001); 5, P. pantotrophus (Robertson \& Kuenen, 1983; Dworkin, 2001). +, Positive; -, negative; NA, no data available.

\begin{tabular}{|c|c|c|c|c|c|}
\hline Characteristic & 1 & 2 & 3 & 4 & 5 \\
\hline Optimal pH & $6 \cdot 5-7 \cdot 5$ & $6 \cdot 5-7 \cdot 5$ & $7 \cdot 0-8 \cdot 0$ & $7 \cdot 5-8 \cdot 0$ & NA \\
\hline Nitrate reduction & - & + & - & - & + \\
\hline \multicolumn{6}{|l|}{ Utilization of: } \\
\hline Sucrose & - & + & + & + & NA \\
\hline D-Fructose & - & + & + & + & + \\
\hline Inositol & - & + & + & NA & NA \\
\hline D-Mannitol & - & + & + & + & NA \\
\hline Mannose & - & + & + & NA & + \\
\hline Lactose & - & - & NA & - & - \\
\hline Arabinose & + & + & + & + & - \\
\hline Glutamic acid & - & NA & + & + & + \\
\hline \multicolumn{6}{|c|}{ Sulfur compounds used for energy } \\
\hline Thiosulfate & + & + & - & + & + \\
\hline Sulfide & + & + & NA & + & + \\
\hline DNA G + C content $(\mathrm{mol} \%)$ & $61 \cdot 3$ & $65-68$ & $67 \cdot 0$ & $67-68$ & 66 \\
\hline
\end{tabular}


The nearly complete $16 \mathrm{~S}$ rRNA gene of strain LW $36^{\mathrm{T}}$ (1343 bp) was amplified and sequenced as described by Zhang et al. (2003). Alignments of $16 \mathrm{~S}$ rRNA gene sequences were performed with the CLUSTAL_X program, version 1.64b (Thompson et al., 1997). A neighbour-joining (Saitou \& Nei, 1987) phylogenetic tree (Fig. 1) was constructed based on evolutionary distances calculated with the Kimura twoparameter model. When aligned, positions with insertions or deletions were excluded from the calculations. The $16 \mathrm{~S}$ rRNA gene sequence analysis indicated that strain LW $36^{\mathrm{T}}$ was phylogenetically related to members of the genus Paracoccus, with similarities ranging from $92 \cdot 4$ to $94 \cdot 9 \%$.

Based on our phenotypic and phylogenetic studies, it is clear that strain $\mathrm{LW} 36^{\mathrm{T}}$ represents a member of the genus Paracoccus. Strain $\mathrm{LW} 36^{\mathrm{T}}$ showed a range of phenotypic characteristics that differentiated it from recognized species of the genus (as listed in Table 1). Its phylogenetic divergence (Fig. 1) also differentiates strain LW36 ${ }^{T}$ from recognized Paracoccus species. Therefore, we conclude that strain LW36 ${ }^{\mathrm{T}}$ represents a novel species of the genus Paracoccus, for which the name Paracoccus sulfuroxidans sp. nov. is proposed.

\section{Description of Paracoccus sulfuroxidans sp. nov.}

Paracoccus sulfuroxidans (sul.fur.ox'i.dans. L. n. sulfur sulfur; N.L. part. adj. oxidans oxidizing; N.L. part. adj. sulfuroxidans pertaining to the ability to oxidize sulfur).

Cells are Gram-negative, coccoid to short rods, $1 \cdot 0-1 \cdot 2 \times 0.5 \mu \mathrm{m}$ in size. Colonies are cream-coloured, smooth, circular and $0 \cdot 4-2 \cdot 0 \mathrm{~mm}$ in diameter. Growth occurs over a temperature range of $25-36{ }^{\circ} \mathrm{C}$ (optimum growth at $31 \cdot 5-33 \cdot 5^{\circ} \mathrm{C}$ ) and a $\mathrm{pH}$ range of $5-10$. Positive for catalase and oxidase activities. Negative for VogesProskauer reaction and lipase activity. Does not hydrolyse gelatin, starch or casein. Utilizes citric acid, nitrilosides, L-arabinose, D-glucose and maltose, but not D-arabitol, fructose, mannitol, rhamnose, melibiose, xylitol, malic acid, L-glutamic acid, L-lactic acid, cellobiose, D-lactose, inositol, D-mannose, D-melibiose, raffinose, D-ribose, salicin, sorbitol, glycerol, trehalose or dextrin. Grows chemolithotrophically on thiosulfate, sulfide and elemental sulfur but not on sulfite. The sole respiratory quinone is Q-10. The predominant cellular fatty acid is $\mathrm{C}_{18: 1} \omega 7 c(64 \cdot 2 \%)$. The $\mathrm{G}+\mathrm{C}$ content of the DNA is $61 \cdot 3 \mathrm{~mol} \%\left(T_{\mathrm{m}}\right)$.

The type strain, LW $36^{\mathrm{T}} \quad\left(=\mathrm{CGMCC} 1.5364^{\mathrm{T}}=\mathrm{JCM}\right.$ $\left.14013^{\mathrm{T}}\right)$, was isolated from activated sludge of a wastewater-treatment bioreactor.

\section{Acknowledgements}

This work was supported by grants from the National Natural Science Foundation of China (30230010) and Chinese Academy of Sciences (KSCX2-SW-113).

\section{References}

Allen, M. B. (1959). Studies with Cyanidium caldarium, an anomalously pigmented chlorophyte. Arch Mikrobiol 32, 270-277.

Collins, M. D. (1985). Isoprenoid quinone analysis in classification and identification. In Chemical Methods in Bacterial Systematics, pp. 267-287. Edited by M. Goodfellow \& D. E. Minnikin. London: Academic Press.

Davis, H. D., Doudoroff, M. \& Stanier, R. Y. (1969). Proposal to reject the genus Hydrogenomonas: taxonomic implications. Int $\mathrm{J}$ Syst Bacteriol 19, 375-390.

Dong, X.-Z. \& Cai, M.-Y. (editors) (2001). Determination of biochemical properties. In Manual for Systematic Identification of General Bacteria, pp. 370-398. Beijing: Science Press.

Doronina, N. V., Trotsenko, Y. A., Krausova, V. I. \& Suzina, N. E. (1998). Paracoccus methylutens sp. nov. - a new aerobic facultatively methylotrophic bacterium utilizing dichloromethane. Syst Appl Microbiol 21, 230-236.

Dworkin, M. (2001). Prokaryotic life cycles. In The Prokaryotes: an Evolving Electronic Resource for the Microbiological Community, release 3.7. Edited by M. Dworkin et al. New York: Springer. http://link.springer-ny.com/link/service/books/10125/

Gerhardt, P., Murray, R. G. E., Wood, W. A. \& Krieg, N. R. (1994). Methods for General and Molecular Bacteriology. Washington, DC: American Society for Microbiology.

Harrison, A. P., Jr (1983). Genomic and physiological comparisons between heterotrophic thiobacilli and Acidiphilium cryptum, Thiobacillus versutus sp. nov., and Thiobacillus acidophilus nom. rev. Int J Syst Bacteriol 33, 211-217.

Hu, Y.-T., Zhou, P.-J., Zhou, Y.-G., Liu, Z.-H. \& Liu, S.-J. (2004). Saccharothrix xingjiangensis sp. nov., a pyrene-degrading actinomycete isolated from Tianchi Lake, Xinjiang, China. Int J Syst Evol Microbiol 54, 2091-2094.

Katayama, Y., Hiraishi, A. \& Kuraishi, H. (1995). Paracoccus thiocyanatus sp. nov., a new species of thiocyanate-utilizing facultative chemolithotroph, and transfer of Thiobacillus versutus to the genus Paracoccus as Paracoccus versutus comb. nov. with emendation of the genus. Microbiology 141, 1469-1477.

Marmur, J. \& Doty, P. (1962). Determination of the base composition of deoxyribonucleic acid from thermal denaturation temperature. J Mol Biol 5, 109-118.

Rainey, F. A., Kelly, D. P., Stackebrandt, E., Burghardt, J., Hiraishi, A., Katayama, Y. \& Wood, A. P. (1999). A re-evaluation of the taxonomy of Paracoccus denitrificans and a proposal for the combination Paracoccus pantotrophus comb. nov. Int $J$ Syst Bacteriol 49, 645-651.

Robertson, L. A. \& Kuenen, J. G. (1983). Thiosphaera pantotropha gen. nov. sp. nov., a facultatively anaerobic, facultatively autotrophic sulphur bacterium. J Gen Microbiol 129, 2847-2855.

Saitou, N. \& Nei, M. (1987). The neighbor-joining method: a new method for reconstructing phylogenetic trees. Mol Biol Evol 4, 406-425.

Thompson, J. D., Gibson, T. J., Plewniak, F., Jeanmougin, F. \& Higgins, D. G. (1997). The CLUSTAL_X windows interface: flexible strategies for multiple sequence alignment aided by quality analysis tools. Nucleic Acids Res 25, 4876-4882.

Wu, C., Lu, X. \& Qin, M. (1989). Analysis of menaquinone compounds in microbial cells by HPLC. Microbiology [English translation of Microbiology (Beijing)] 16, 176-178.

Zhang, D., Yang, H., Zhang, W., Huang, Z. \& Liu, S.-J. (2003). Rhodocista pekingensis sp. nov., a cyst-forming phototrophic bacterium from a municipal wastewater treatment plant. Int J Syst Evol Microbiol 53, 1111-1114. 